DOI: $10.51384 /$ cert-08.15

\title{
JÁNó MihÁLY*
}

\section{A SZÉKELYDERZSI TEMPLOM FESTETT TRIPTICHONJA}

\author{
Kulcsszavak: megrendelő; donátor; önarckép; intercesszió
}

A székelyderzsi unitárius templomnak a 16. században bemeszelt középkori falképeit első alkalommal 1887 nyarán tárta fel Huszka József (1854-1934) sepsiszentgyörgyi rajztanár. ${ }^{1}$ 2008-ban a marosvásárhelyi Imago Picta cég munkatársai Pál Péter vezetésével újabb részleteket tártak fel, és a teljes falképegyüttest restaurálták. ${ }^{2}$

A templomhajó északi hosszfalát, a déli fal festményeivel együtt, az 1419-ben festett Szent László-legenda jelenetei borítják. Ennek kiegészítő elemei Szent Kozma és Damján, valamint Remete Szent Antal ábrázolása. Kisebb töredékek láthatók még az alsó sávban: a karzat alatt, a fentiekkel azonos stílusban festett Tízezer vértanú falképének fennmaradt részlete, és több, korábban, vagyis a 14. században festett, ma már értelmezhetetlen falkép.

Dolgozatomban a templomhajó déli hosszfalán megfestett falképegyüttes (püspökszentek, Szent Mihály, Saul megtérése-jelenetek) kutatástörténetét és a kutatás során felmerült ikonográfiai elemzéseket veszem számba, annak reményében, hogy a közel 150 év folyamán közzétett múvészettörténeti tanulmányok és a saját kutatásaim eredményeivel talán sikerül közelebb kerülni a székelyderzsi falfestmények keletkezésének körülményeihez. (1. kép)

\section{KUTATÁSTÖRTÉNET}

A székelyderzsi falképeket az első, 1887 nyarán történt feltárását követően Huszka József a korábbi években felfedezett falképekkel együtt írta le röviden, a Sepsiszentgyörgyön megjelenő Székely Nemzet c. napilapban:

* Jánó Mihály (1945), dr., művészettörténész, jano.mihaly@yahoo.com.

1 Jánó Mihály: Szinek és legendák. Tanulmányok az erdélyi falfestmények kutatástörténetéhez. Székely Nemzeti Múzeum-Pallas Akadémia, Sepsiszentgyörgy-Csíkszereda, 2008 (a továbbiakban Jánó: Szinek és legendák). 97-99.

2 Pál Péter-Kiss Lóránd-Minály Ferenc: A székelyderzsi unitárius templom falképeinek restaurálása $=$ Székelyek a keleti végeken. Szerk. Sashalmi-Fenete Tamás. SzékelyudvarhelySzékelyderzs. 2020 (a továbbiakban Székelyek a keleti végeken). 67-80; PÁL Péter-Kiss Lóránd: Restaurarea picturilor murale din nava bisericii unitariene din Dârjiu. Art Conservation Support, Buc., [2014] (Colecția restaurări). 
„[...] A déli fal három teljes ornatusban levő fôpapot, szent Mihály arkangyalt, lelket mérlegelve és teljes vasba öltözötten adja elénk. Azonkívül, Saul megtérését. Nagy lovas alakkal Ananiással és felhőkből fényt szóró Jézussal. [...]A Sault kisérő fegyveresek egyike ugyanis zászlót tart kezében, melyen a következő felírás olvasható a rövidítések kiegészítésével: Hoc opus fecit de pingere seu praeparare magister Paulus filius Stephani de ung anno domini millesimo quadringentesimo decimo nono: scriptum scribebat et pulchram puellam in mente tenebat. Tehát 1419-ben festette Pál mester Ungi István fia.[...]”. ${ }^{3}$

Huszka József szerint a zászlón olvasható feliraton Ungi István fia, Pál mester mint festő örökítette meg a nevét, aki a 15. században múködő székely festőiskola egyik képviselője volt. A székely festőiskolára vonatkozó megállapítását röviden megismételte a Múemlékek Országos Bizottságához írt egyik jelentésében, amelyhez rajzokat és fényképeket is mellékelt. ${ }^{4} \mathrm{Az}$ akvarellmásolatok és fotók alapján kisebb vita keletkezhetett a bizottság tagjai között a falképek német vagy olasz festészetbe való besorolásáról.

Henszlmann Imre (1813-1888) a következőképpen fejtette ki a véleményét:

„[...] E falképek, melyeken az 1419. év van feljegyezve, az egykorú hasonnemú német múvek szellemének sehogy sem felelnek meg, hanem megfelelnek, nézetem szerint, az ezen időben felviruló flórenczi iskolának. [...] A székelyföldi képek közti kiválóságuk és múvészeti értékök fölötte kívánatossá teszi, hogy a derzsi falképek jó állapotban fenntartassanak [...]". ${ }^{5}$

1888-ban Huszka az Archaeologiai Értesítőben már külön cikket szentelt a derzsi falképeknek:

„[...]A déli fal első képcsoportja négy, püspöksüveges és pásztorbotos szentet ábrázol. A fejük mellett $\mathrm{S}$. Khilians és S. Sath. olvasható. A mellette lévő képen Mihály arkangyalt látjuk teljesen vasba öltözve, egyik kezében mérleggel, a másikban lándzsával, melyet a letapodott sárkány szájába szúr. [...]

3 Huszka József: A mi székely festôiskolánk a XV. században. Székely Nemzet V[1887]. 99. sz. 2.

4 Közölve Jánó: Szinek és legendák. 99.

5 [Henszlmann Imre:] Különfélék. Archaelogiai Értesító. Új folyam 8(1888). 2. füz. 84-85. 
A következő képcsoport Pál megtérését ábrázolja. A lováról lebukó Saul fejére teszi bal kezét a barátcsuklyás Ananiás, míg jobbját felemelve beszél. [...] A Saul és kísérete feje fölött felhőkből könyvet kezében tartó Jézus látszik, a mint más kezét áldólag kinyújtva fénysugarakat szór Saulra és Ananiásra [...]”. ${ }^{6}$

A következő évtizedekben szórványosan emlékeznek meg a derzsi falképekről. Csak 1933-ban olvashatunk hosszabban kifejtett véleményt a falképek stílusáról. Gróh István (1867-1936) iparművész, tanár, a magyarországi középkori falfestészet jeles kutatója és másolatok készítője az egyik írásában megjegyezte: „Nos, ennek az unitárius templomnak legfőbb ékessége az a falkép, amely Szt. Lászlót és a cserhalmi ütközetet ábrázolja. Ezt a képet pedig éppúgy, mint a többit, keleti mester festette. A részletekbe nem bocsátkozhatom, de erre vall a stílus. [...]”. ${ }^{7}$

Az első világháború után a román múvészettörténészek közül Victor Brătulescu (1899-1976) írt első alkalommal hosszabban a derzsi templomról. Brătulescu a bukaresti Történelmi Múemlékek Bizottságának titkára volt 1923 és 1936 között, majd az Egyházművészeti Múzeum (Muzeul de Artă Religioasă) igazgatója 1936-tól 1938-ig. ${ }^{8}$ Miután meglátogatta a templomot, az utóbbi minőségében ajánlotta 1938ban az épület felvételét az ország múemlékei közé. ${ }^{9}$ A derzsi látogatás után született Brătulescu Biserici din Transilvania. Biserici intărite (Erdélyi templomok. Erődített templomok.) c. tanulmánya, amelyben az építészeti megfigyelései mellett a falképekrôl is megemlékezett. Nem térünk ki a Szent László-ciklus jeleneteinek vagy az ábrázolt személyek helytelen értelmezésére, csak a templomhajó déli hosszfalán lévő falfestményekről írt észrevételeit említjük meg. Brătulescu szerint a damaszkuszi útnak nevezett jelenetben az látható, amint Szent Pál apostol lebukik a lováról, előtte feltűnik egy öreg személy, fölötte pedig Jézus. A Szent Pált kísérő lovasok középkori öltözetet viselnek. Valamivel távolabb, az ortodoxok Mihály arkangyala látható, kezében mérleget tart, karján egy lélek. Tovább elemezve a képet, a lélekmérő Szent Mihály jellegzetes ábrázolását írja le, megállapítva, hogy ez a képi motívum szinte minden román templomban megfestett Utolsó ítéletben megtalálható. Továbbá a szerző, az általa közölt fénykép ellenére, amelyen jól felismerhetők a püspöki ornátusban

6 Huszka József: A derzsi (Udvarhely m) falképek. Archaeologiai Értesítő. Új folyam 8(1888). 1. füz. 50-53.

7 Grón István: A bizánci keresztény müvészet elsó emlékei Erdélyben = Erdély eloláhosodása. Bp., 1933. 18-19. Gróh „bizánci stílus”-ban megfestett falképeknek tartotta még Erdélyben az őraljaboldogfalvi, zeykfalvi, malomvízi és a dévai templomok falfestményeit.

8 Enciclopedia istoriografiei românești. Red. Alexandru Stănciulescu. Științifică și Enciclopedică, Buc., 1978. 73.

9 Ioan Opriș: Protejarea mărturiilor cultural-artistice din Transilvania și Banat după Marea Unire. Științifică și Enciclopedică, Buc., 1988. 79. 
megfestett alakok, a csoportot meglepő módon a Háromkirályok ábrázolásaként értelmezte. Brătulescu természetesen kitért a Saul megtérése-jelenetben megfestett zászló feliratára is, lefordítva a latin szöveget román nyelvre, Pál mestert a falképek festőjeként nevezte meg. Végül a lábjegyzetben a felirat utolsó mondatával kapcsolatban felvetette, hogy Pál mester talán egy valahol Magyarországon élő lányra gondolt, vagy a festők szokása szerint, Szűz Máriához imádkozott, hogy megsegítse a munkájában. Hozzátette, hogy a felirat inkább az előbbi elképzelés miatt született. ${ }^{10}$

Ion D. Ștefănescu (1886-1981) művészettörténész, a bizánci ikonográfia kutatója az 1938-ban közzétett munkájában ${ }^{11}$ részletesen elemezte az erdélyi román, középkori templomok múvészetét, ugyanakkor néhány székelyföldi falusi templom középkori falképeiről is írt. Meglátogatva Gelence, Csíkszentmihály, Csíkrákos (Göröcsfalva), Csíkdelne, Kilyén, Csíkmenaság, Bögöz, Felsőboldogfalva, Kőröspatak templomait, a freskókról szóló hosszabb rövidebb leírásai között kitért a derzsi ciklusokra is. A templomhajó déli hosszfalán látott, mérleget tartó Szent Mihály arkangyal ábrázolás alapján egy Utolsó ítélet kompozícióra gondolt. A püspöksorozatot, amelyet részben mészréteg takart, nem ismerte fel. A Saul megtérése-jelenetben megfestett zászló minuszkulás felirata alapján, amelyet nyomtatott nagy betúkkel másolt le, Pál mestert az 1419-ben készült festmény megrendelójeként értelmezte. A falképek leírását a következőkkel zárta: „Említsük meg ismét, hogy Pálnak hívták a donátort, neve ott szerepel az elöl haladó lovag zászlaján. Szent Pál alakja nagy valószínúséggel az ô portréja". ${ }^{12}$

Ștefănescu egy élete utolsó évében, 1981-ben megjelent tanulmányában feltételezte, hogy a püspöksorozat Szent Ágostont, Nagy Szent Gergelyt, Szent Ambrust ábrázolja. A Saul megtérése-jelenetet, mintha nem látta volna személyesen a falképeket, meglehetôsen zavarosan írta le és értelmezte. Az egyik lovasról mint fiatal lányról beszélt, vagy a sisakos, glória nélküli másik lovagot, ha kérdőjelesen is, de védőszentként értelmezte. Nem hivatkozott rá, de bizonyára tudott már ekkor Dávid László feltételezéséről, amely szerint a megrendelőt az Ungi-Nagymihályi család körében lehetne megkeresni, és annak a személyes életében történtekre utalhat az apostol megtérésének jelenete. ${ }^{13}$

10 Victor Brătulescu: Biserici din Transilvania. Biserici intărite. Buletinul Comisiunii Monumentelor Istorice XXX(1937). 4-5.

11 I. D. Ștefănescu: L'art byzantin et l'art lombard en Transylvanie. Peintures murales de Valachie et de Moldavie. Librairie Orientaliste Paul Geuthner, Paris, 1938.

12 Uo. 57-59.

13 Uó: Arta feudală în Țările române. Pictura murală și icoanele de la origini pînă în secolul al XIX-lea. Editura Mitropoliei Banatului, Timișoara, 1981. 68-69. Az idevonatkozó rész eredeti szövege: „Paulus e magistru, rang de noblețe administrativ și militară din Maramureș și senior din Ung, teritoriu aparținînd acestei provincii. [...] Pictorul a asemuit evenimentul capital din viața apostolului cu un episod, nelămurit pentru noi, din viața magistrului”. 
Genthon István (1903-1969) az egyik, 1934-ben megjelent tanulmányában, miközben röviden számba vette a magyarországi és erdélyi középkori falképeket, jórészt a Ștefănescu korábban megjelent könyvében ${ }^{14}$ szereplő ortodox templomok festett emlékeit jellemezte. A derzsi falképeket mint a bizánci hatás legjobb emlékét említette meg. ${ }^{15}$

Tudomásunk szerint Genthon István nem járt a derzsi templomban, annak falképeit és a zászló feliratát csak a másolatokból ismerhette, és azok alapján fogalmazta meg a véleményét, amely szerint Ungi Pál a falképek festője volt (az 1414-es évszám csak elírás lehet). Mindezt egy 1936-ban megjelent tanulmányában újra megismételte. ${ }^{16}$

Balogh Jolán (1900-1988) Az erdélyi renassaince c. összefoglaló, nagy munkájában hosszabban foglalkozott a derzsi falképek formai és stiláris jellegzetességeivel. Mint írta:

„Az erdélyi renaissance első nagy múvéhez, a Hunyadi tumbához [...] a Szent László falfestményeken keresztül egyenes út vezet. A fejlődésnek ez a vonala a XV. sz. első felében sem szakadt meg, sőt éppen ebből a korból való az egyik legszebb sorozat, a székelyderzsi, melyet 1419-ben festetett Pál, Ungi István fia. [...] Stílusa elvont és síkszerú, sajátos jellemvonásaiban a magyar képzeletnek dekoratív, meseszövő hajlamai törnek felszínre”.

A neves múvészettörténész összefoglalta a derzsi falképek addigi irodalmát, ugyanakkor kitért még a Pál mester által megrendelt derzsi festmények és a bizánci művészet kérdésére is:

„A bizánci mưvészettől azonban, mellyel többen tévesen összekapcsolták, távol áll. Annak hieratikus, merev kompozíciói, előirt, megszabott rendszeressége, manierisztikus alakjai erősen elütnek a derzsi sorozat stílusától. [...] Jellemző, hogy még Stefanescu sem talált a derzsi freskókon bizánci hatást". ${ }^{17}$

14 Uő: La peinture religieuse en Valachie et Transylvanie depuis les origines jusqu'au XIXe siècle. Librairie Orientaliste Paul Geuthner, Paris, 1932.

15 Genthon István: Az ortodoxia müvészete Erdélyben. Magyar Szemle 22(1934). 9-12. sz. 245.

16 Uő: Erdély müvészete. Bp., 1936. 572, 573. http://adatbank.transindex.ro/html/alcim_ pdf9314.pdf (Utolsó megtekintés: 2021. 03. 27.)

17 Balogh Jolán: Az erdélyi renassaince. Erdélyi Tudományos Intézet, Kvár, 1943. 33. 
Radocsay Dénes (1918-1974), aki nem látta személyesen a derzsi falképeket, csak a Huszka József által készített akvarellmásolatokat és a Szépmúvészeti Múzeumba került (ma a Nemzeti Galériában található) két freskótöredéket ismerte, elsősorban a festett feliratból kiindulva fejtette ki gondolatait. Azt hangsúlyozta, hogy a falképegyüttes a késő gótikus festészet laicizálódásának egyik példája a magyarországi művészetben. A szerző Ungi Pál mestert a falképek megrendelőjének tekintette, és a csillagmintás háttért említve jegyezte meg, hogy a derzsi festő formai megoldásai a 14. századi itáliai művészetre vezethetók vissza. ${ }^{18}$ (2. kép)

Virgil Vătășianu (1902-1993) az 1959-ben megjelent Istoria artei feudale în Țările Romîne c. nagy, összefoglaló munkájában a székelyderzsi falképek stílus- és ikonográfiai elemzése is helyet kapott. A korábbi szerzőkhöz hasonlóan Vătășianu is az északitáliai korai reneszánsz festészettel rokon stíluselemeket említett a derzsi falfestményeken a viselet, a páncélzat és a háttérbrokát mintájával kapcsolatban. Úgy tűnik, nem járt Székelyderzsen, csak a közölt rajzok és fényképek alapján alkotott véleményt. Könyvéből a templomhajó déli oldalán található falképekről szóló részleteket emelem ki. „A déli falon ugyanaz a festő dolgozott, mint az északin. A diadalív mellett két püspök látszik" - írja a szerzőnk. Jegyzetben hozzátette, hogy nyilvánvalóan nem a Királyok imádásának jelenete van itt megfestve, amint azt Brătulescu vélte. Szintén csak néhány szóban tért ki a lélekmérő Szent Mihály ábrázolásra, amellyel kapcsolatban megjegyezte, hogy „ez a jelenet nem feltétlenül egy nagyobb Utolsó ítélet ábrázolás része, ahogyan Ștefănescu gondolta, csak a bizánci ikonográfiában illeszkedett az Utolsó ítélet ábrázolásokba a lélekmérő Szent Mihály alakja." A Saul megtérése-jelenetrôl a zászló felirata alapján írta Vătășianu: „Ez a jelenet tehát egyfajta votív kép, lévén a patrónus Ungi Pálnak ajánlva, magába foglalva a festmények készítésének ritka és értékes 1419-es évszámát, együtt a reneszánszra jellemző világi indiszkrécióval az alapító nosztalgikus szerelméről”. ${ }^{19}$

Az 1960-as évek elején tervbe vették a templomépület és a falképek helyreállítását. 1962-ben templom restaurálási dokumentációjának összeállításakor a nagytekintélyű és jó emlékű Eugenia Greceanu (1928-2016) bukaresti múemlékes építész a következőképpen jellemezte a templom falképeit: „Az Ungi István fia, Pál mester által 1419-ben készített belső festmény egyik ritka példányát jelenti az olasz kora reneszánsz (trecento) hatásának Erdélyben, és kivételes értéket képvisel a kompozíció kifejező erejével és a színek frissességével”. ${ }^{20}$

18 Radocsay Dénes: A középkori Magyarország falképei. Akadémiai, Bp., 1954. 62-64.

19 Virgil Vătășianu: Istoria artei feudale în Țările Romîne. I. Arta în perioada de dezvoltare a feudalismului. Editura Academiei Republicii Populare Romîne, Buc., 1959. 425-426.

20 Institutul Național al Patrimoniului (Nemzeti Örökség Intézete) Irattára, leltári szám: 4392 Dîrjiu, Harghita, Biserica unitariană, 1961-1970. 
Vasile Drăguț (1928-1987) műkritikus, mûvészettörténész, több művészeti intézmény vezetóje, az 1970-es években a legtöbbet publikáló múemlékes szakember volt Romániában. Mint a romániai múemlékvédelem vezető személyisége, a székelyföldi múemlék-helyreállítási munkálatok irányítója is volt évekig (1968-1976). Számos tanulmányt, cikket írt a középkori falfestészet ikonográfiája témakörében. A székelyderzsi templom falképeinek vizsgálata során a zászló latin feliratában szereplő Ungi Pál mestert nem a falképek megrendelőjeként, hanem mint a freskók festőjének nevét értelmezte, és a mester múvészetének különböző sajátos jegyeit írta le. Szerinte a derzsi falképegyüttes festójének, Ungi Pálnak a múvészete nyilvánvaló kapcsolatot mutat a nyugati udvari környezettel, ezzel együtt az italo-bizánci stílus képviselője. A Saul megtérése kompozícióról szólva, arra hívta fel a figyelmet, hogy a lóról leeső apostol mozzanata kevésbé fontos képelemnek látszik, mint a kíséretét alkotó lovascsoport, amelyben kitúnik a mester robusztus és nyers alakja. „Ungi Pál önarcképe nem csupán az ábrázolás kitüntető módja által azonosítható - taglalta Vasile Drăgut, -, hanem avval a festett felirattal is, amely a feje fölött lobogó zászlón olvasható.” A zászló feliratát pedig a következőképpen értelmezte: „Ezt a munkát festette és előkészítette Pál mester, Ungi István fia, az Úr ezernégyszáz tizenkilencedik éve. Írtam és egy szép lány járt az eszemben”. ${ }^{21}$

Talán hajlamosak lehetünk a szerző Ungi Pál önarcképére vonatkozó megállapítását elfogadni, ha számba vesszük a következő lehetséges érveket, amelyeknek kifejtésére nem került sor.

\section{UNGI PÁL, A FESTŐ-DONÁTOR}

Sault, a későbbi Pál apostolt, a damaszkuszi úton legtöbb esetben népes katonai kísérettel együtt ábrázolták a 15. századi festészetben. A derzsi falképen viszont csak három szereplőt látunk kíséretként megfestve. Közülük kitűnik a sodronyinges, sisakos, sötétbarna bajuszú és szakállú, idősebb lovag, arccal a nézővel szembe fordulva. Mögötte egy mellvértbe öltözött, hajadonfőtt lévő, fiatalabb lovast láthatunk, aki figyelmesen néz az idősebb társára. A harmadik szereplő egy ijedt arcú, világos színú ruhát viselő ifjú, aki a nyeregben felemelkedve, a lovon előrebukó Saul köpenyét tartja. ${ }^{22} \mathrm{~A}$ középső lovag a festő portréja lehet, akinek a tekintete mereven a nézőre irányul, széles arccsontja, hegyes orra és a szakálla is egyénivé teszi az ábrázolását, fésületlen, barna szakálla természetesebb, mint a Saulé vagy Ananiásé. (3. kép)

21 Vasile DrăguȚ: Arta gotică în România. Meridiane, Buc., 1979. 228-230.

22 Hasonló, Saul köpenyét tartó mozdulatot láthatunk például Aragóniai Márton 1380-1450 k. készült breviáriumának egyik miniatúráján: https://gallica.bnf.fr/ark:/12148/ btv1b52000996s/f620.image (Utolsó megtekintés: 2021. 03. 28.) 
A derzsi festő arcképéhez hasonló frontális vagy háromnegyed profilos művészönarcképet, amely egy-egy csoportban jelenik meg, többet ismerünk a 15. századból. Itt csak a legismertebbekből említek meg néhányat: Benozzo Gozzoli önarcképe a Háromkirályok kíséretében a firenzei Palazzo Medici-Riccardi, Háromkirályok-kápolna freskóján (1459 k.), Filippo Lippi önarcképe a spoletói dóm Mária halála-freskóján (1467-1469k.), Pietro Perugino önarcképe a vatikáni Sixtus-kápolna Jézus átadja Szent Péternek a mennyország kulcsait c. freskóján (1479). A derzsi freskóval közel egy időben, 1401-ben készült a montepulcianói Santa Maria dell'Assunta-dóm Szűz Mária elszenderedése-oltár, amelynek festője Taddeo di Bartolo (1363-1422) a névadója, Szent Júdás Tádé portréjaként festette meg a saját önarcképét, egyetlen olyan szereplőjeként a festménynek, akinek a tekintete a nézőre irányul. Nem lehet véletlen, hogy Ungi Pál festő, Pál apostol életének legjelentősebb pillanatát megfestve, a saját önarcképét is elhelyezte a kompozícióban. Ugyanakkor az ő és fiatalabb társa páncélos viselete utalás Saul katonai kíséretére a damaszkuszi úton.

Ungi Pál festő mivoltát erősítheti meg a magister kifejezés is. A zászló feliratán magát magisternek nevező Ungi Pálhoz hasonlóan Johannes de Rosenau, a nagyszebeni Szűz Mária-plébániatemplom szentélyében látható monumentális Keresztre feszítés falfestmény készítője is magisternek nevezi magát 1445-ben, az Ecce homo fölötti ablakmélyedésben levő feliratban: „Hoc opus fecit magister Johannes de Rozenaw Ann. Domini milesimo quadrigentesimo XLV.” A lónyai református templom szentélyében nemrég feltárt 15. századi falképtöredékek között egy néhány szavas, gótikus minuszkulás írásszalag került felszínre, amelyen a betútípus és a ligatúrák alkalmazása azonos a derzsi feliraton használtakkal. A feltehetően 1413-ban festett felirat egy Miklós mesterről tesz említést: „... mag(iste)r $\bullet$ nicolaus ...e • Anno d(omi) i...•xii ${ }^{23}$ A magister talán a lónyai falképek festője lehetett.

Számtalan példát lehetne még felsorolni arra, hogy a festők magisterként nevezik meg magukat, így Ungi Pál esetében is erre gondolhatunk. Arra a kérdésre pedig, hogy ki a másik két fiatal szereplő a falképen, a lehetséges válasz az lehet, hogy ők voltak a mestertársai a templomhajó nagy felületen történő kifestésében. Hogy miként zajlott a két festő és a festéktörő segéd együttes munkája, vagyis a falfestés egy épületben, jól szemlélteti például egy 1415 körül festett francia Biblia-illusztráció (1 Királyok 7,1-12), amelyben a két festő az előrajzot, majd a kifestést végzi, a fiatal segéd pedig a festéket készíti elő. ${ }^{24}$ (4. kép)

23 JÉkely Zsombor-LÁngi József: Lónya (egykor Bereg vármegye, ma Szabolcs-Szatmár Bereg megye). Református templom = JÉKELY Zsombor-LÁNGi József: Falfestészeti emlékek a középkori Magyarország északkeleti megyéiböl. Szerk. Kollár Tibor. Teleki László Alapítvány, Bp., 2009. 187.

$24 \mathrm{http} / /$ corsair.themorgan.org/vwebv/holdingsInfo?\&bibId=254463\&searchId=2175\&rec Pointer=0\&recCount=50; (Utolsó megtekintés: 2021. 03. 29.) 
Marosi Ernő a zselízi (Želiezovce, Szlovákia) falképekkel kapcsolatban írja, hogy

„az annyira individuális tartalmú - és már csak az írás uralkodó szerepe miatt is kivételes múveltséget feltételező - képek, mint az arisztokrata Becsei Vesszős György halála utáni megítélését ábrázoló zselízi falkép, nem lehettek általánosak. A tematika egyéni kívánságokat tükröző megválasztás általában legfeljebb addig mehetett el, mint a székelyderzsi ciklusé, ahol ungi István fia Pál mester nyilván nem minden személyes vonatkozás nélkül festette meg Szent László legendája mellett Szent Pál ritkán ábrázolt történetét is. Rejtett votív képre utal, hogy a donátor feliratát a Saul megtérése-jelenet egy zászlója hordozza”. ${ }^{25}$

Itt kell kitérnünk Stefano Riccioni olasz művészettörténész egyik hosszabb tanulmányára, amelyet a középkori liturgikus térben található feliratok és az ábrázolt téma közötti kapcsolatról írt. A szerző az epigrafikus elemeket alapvetőnek tartja a kép ikonográfiai elemzésében, ebből következően a kutatási módszerének megnevezésére az epikonográfia fogalmát vezette be.

Riccioni ebben a tanulmányban fejti ki többek között, hogy a felirat, mielőtt olvasni való szöveggé válna, először mint egy kép jelenik meg a néző számára, és úgy vonja magára a figyelmet. További kutatás szempontjából számít az, hogy hol helyezkedik el a kompozíció, amelyben a szöveg olvasható, esetleg szimbolikus jelentőségú hely is lehet. Vizsgálni való, hogy mennyire látható helyen szerepel a felirat, ezáltal felmérhető, hogy milyen fontosságot szánt az írás szerzője a szövegnek, és nem utolsósorban figyelmet érdemel, hogy kompozíciós szempontból a felirat milyen összefüggésben van a körülötte ábrázolt alakokkal. ${ }^{26}$

Mindezt figyelembe véve, azt láthatjuk a derzsi templomban, hogy a Saul megtérése-jelenetet, azon belül a feliratot tartalmazó zászlót a hajó déli hosszfalán festették meg, a lélekmérő Szent Mihállyal együtt, olyan nyilvános helyen, ahol a templomból távozó hívek jól láthatták, és elgondolkozhattak rajta. Mint ahogy a nem túl távoli

25 Marosi Ernő: Nemesi donátorok = Magyarországi müvészet 1300-1470 körül. I. Szerk. Marosi Ernő. Akadémiai, Bp., 1987.121.

26 Stefano Riccioni: L'Epiconografia: l'opera d'arte medievale come sintesi visiva di scrittura e immagine = Medioevo. Arte e storia, Atti del X. Convegno internazionale di studi (Parma, 1822 sett. 2007). Electa, Milano, 2008. 465-480. https://www.academia.edu/4795660/L_ Epiconografia_1_opera_d_arte_come_sintesi_visiva_di_scrittura_e_immagine_in_ Medioevo_Arte_e_storia_Atti_del_X_Convegno_internazionale_di_studi_ Parma_18_22_sett_2007_Milano_Electa_2008_ISBN_978_88_370_6695_6_ pp_465_480 (Utolsó megtekintés: 2021.03.29.) 
kilyéni kortársaik vagy a valamivel korábban élő gelencei hívek, amikor a templomból távoztak a déli ajtón át, az Utolsó ítélet nagy képciklusa alatt.

A Saul megtérése-jelenetnek Marosi Ernő által említett rejtett votívkép-jellege azáltal értelmezhető pontosabban, ha arra gondolunk, hogy a zászló (labarum) az Ungi Pál nevét tartalmazó felirattal nem véletlenül van elhelyezve annak a lovagnak a feje fölött, akit, Vasile Drăguț feltételezését elfogadva, a fentiekben a festővel azonosítottam.

Mindaz, amit az Ungi Pál feltételezett önarcképéből kiindulva végiggondoltam, talán nem zárja ki a lehetőségét annak, hogy ő maga legyen a falképegyüttes donátora is, aki a 15. századi megrendelő, az olasz commitente-ideatore-fogalom értelmében, a saját érzékenységének és múveltségének megfelelően, a derzsi templomhajó déli oldalán lévő falképek témáját megtervezte és megfestette. Ez viszont csak úgy fogadható el feltételesen, ha a zászló feliratában az Ungi Pál személyére vonatkozóan érvényes „fecit depingere” kifejezés, a megrendelő vagy donátor értelmezése mellett a „praeparare” szót a falképek előkészítéseként fogjuk fel. (5. kép)

A festőre mint donátorra egy másik példát néhány évtizeddel később ismerünk Erdélyben. 1483-1484-ben a segesvári Valentinus pictor, egyben városi tanácsos, később polgármester mint donátor festette meg votív képként a Hegyi templom diadalivén a Veronika kendője motívumot, és a hajó egyik boltmezőjében a démonokkal küzdő Szent Mihály alakját, alatta pedig a festők címerét. ${ }^{27}$

Ungi Pál önarcképéhez hasonlóan járt el a 14. század második felében Vas és Zala megyében dolgozó Johannes Aquila a mártonhelyi (Martjanci, Szlovénia) Szent Márton-templom kifestésekor 1392-ben, amikor a falképegyüttesben a saját portréját is megfestette. Marosi Ernő véleménye szerint:

„Aquila szokatlan öntudata csak azzal a szereppel magyarázható, amelyet a hozzá hasonló vándor festők, mint a liturgiai követelmények és ikonográfiai szokások szakértői tudatlan és inkább csak a kifestést magát igénylő, de annak tartalmi kérdéseiben egészen tanácstalan megbízóikkal szemben játszottak”. ${ }^{28}$

Daniel Spanke szlovén múvészettörténész Aquila mártonhelyi szerepéhez hasonlóan donátori müködését feltételezte a veleméri Szentháromság-templom kifestésében is. ${ }^{29}$

27 Dana Jener: Picturile murale ale Bisericii din Deal din Sighişoara. Ars Transilvaniae XIVXV(2004-2005). 111.

28 Marosi: i.m. 120.

29 Hivatkozik rá Wenli Tünde: Bogyai Tamás és Johannes Aquila. Ars Hungarica XXXVIII(2012).3.sz. 350. 
Egy korábbi tanulmányomban ${ }^{30}$ fogalmaztam meg, hogy Szent Pál megtérésének jelenete és a jelenet rejtett votív képre utaló felirata, valamint Szent Mihály eszkatologikus jellegű képe és a püspökszentek a jó halál, vagyis az ars bene moriendi képzetkörét idézik. Az ars moriendi elemei: „elmélkedések a halálról, vigasztalások, figyelmeztetés a bủnbánatra, az ellenséggel való kibékülésre és a hit megerősítésére, imádságok és a szentek segítségül hívása" ${ }^{31}$ Fontos számunkra, hogy mindez a festő kortársai által írt irodalmi alkotásokban fogalmazódott meg a 15. század elején. Így Johannes Gerson (1363-1429) Opus tripartitum de praeceptis decalogi de confessione et de arte moriendijében s az Európában rendkívül népszerú Tractatus (Speculum) artis bene moriendi (1415) címú alkotásban. Feltételezhető, hogy az alapos teológiai múveltséggel rendelkező festő jól ismerte e két művet és az ars bene moriendi gondolatrendszerét. Ebben az értelmezésben fogalmazhatta meg, mintegy nagy, hármas osztású oltárképben, triptichonban a maga gondolatait. Így kaphatott helyet a triptichon püspökei között Szent Kilián, a festők védőszentje, és Szent Szaturninusz, a jó halál patrónusa. Ugyanakkor Pál mester az önarcképét a védőszent, Szent Pál élete nagy fordulójának felidézésével együtt festette meg a jobb oldali kompozícióban, ezzel személyessé téve az ábrázolt jelenetet. A jelenet felső részében megfestett Jézus az átlényegüléseként értelmezett ostyát hullatja a misszióra kiválasztott apostolra. (Nagyon érdekes, hogy az aláhulló ostyák nem takarják be az apostol felett előrehajló, világos színű ló - amelyen a festő ül - erőteljes ecsetvonásokkal ábrázolt fejét és sörényét.)

A püspökök és a Szent Pál megtérése-jelenet között, teljes lovagi vértezetben Szent Mihály arkangyal egyszerre jelenik meg mint a sárkány legyőzője és a lelket mérô szent, ahogy megfestették rendszerint az Utolsó ítélet ábrázolásokban. ${ }^{32}$

Figyelmet érdemel, hogy a három jelenet között egyenlő szélességű, keskeny sáv maradt szabadon, amely valamilyen (gipsz-, fa)keret lenyomata lehet.

A lélekmérő szent bal karján kicsi, meztelen felsőtestú női figurát látunk imára összekulcsolt kezekkel, a közvetítésért (intercesszió) könyörögve. A kétkarú mérleg nehezebb serpenyőjében ülő női alak, a lélek (anima) megtestesítője látszik, feje körül kis, fehér színű, kerek ostyákkal. A másik, könnyebbnek bizonyuló serpenyőbe ördögök kapaszkodnak, egyikük a derekára kötött malomkővel. (6. kép)

30 Jánó Mihály: Ungi Pál mester imája a székelyderzsi templomban = Fogalom és kép 2. A kolozsvári Babeș-Bolyai Tudományegyetem Filozófia Tanszékcsoportjának magyar tagozata által szervezett nemzetközi tanérkezdő konferencia elöadásai. Szerk. Egyed Péter-GáL László. Presa Universitară Clujeană, Kvár, 2011 (a továbbiakban Jánó: Ungi Pál mester). 142-149.

31 Diós István: Ars moriendi = Katolikus lexikon. I. Szerk. Diós István. Szent István Társulat, Bp., 1993. 417-418.

32 Apokalipszis, Jel 12, 7 skk. 
A Szent Mihály karján megjelenő lány kapcsán vetődött fel a gondolata annak, hogy reá vonatkoztatható talán a festőnek az a mondata, amelyet a zászlón megfogalmazott: „Az iró irta és az eszében a szép lányt tartotta” (Benkő Elek fordítása). E sorok írójának 2011-ben, majd Marosi Ernő 2012-ben közölt tanulmányában felmerült annak a lehetôségnek a gyanúja, hogy a felirat készítésekor Pál mester a szeretett és elhunyt kedvesére gondolt, akit a lélekmérő szent védelmébe ajánlott. ${ }^{33}$ Ezt tovább gondolva, Marosi felvetette azt a kérdést, hogy

„... szabad-e egyszerűen csak a képek logikáját követni a szövegeket helyettesítő forrásokként. Vagy feltételeznünk kell egy erős individuális gesztust, szokatlan szóbeli kommunikációt a donátor és a festő között; így különböző múvészi kifejezésmódok közötti határok ledöntésével - mint esetünkben - a kultikus képekbe narratív elemek beviteléről van szó. A hipotézisünk alapját képező erős individualizmus nem annyira különös ebben a korszakban - 1419 azontúl, hogy erősen kapcsolódik ahhoz a kérdéshez, hogy mi lesz a lélek sorsa a halál után”. ${ }^{34}$ (Szász Fejér Gyöngyi fordítása)

A mondatnak másik értelmezése szerint a szép lány, a „pulchra puella” a középkori kéziratok kolofonjaiban gyakran előforduló kifejezés, amelyet a scriptorok különböző értelemben használtak, rendszerint a munkájukért kívánt égi jutalomra gondolva, máskor pedig diákos, pajzán kifejezésekhez társítva. ${ }^{35}$ Vladimir Agrigoroaei müvészettörténész is hosszabb tanulmányt szentelt a témának. Figyelemre méltónak tartja, hogy a derzsi felirat a 15. század elején keletkezett, amikor a pulchra puella kifejezés a virágkorát élte a német kéziratok kolofonjában. Szerinte is nyitott kérdés a lány kiléte, amely a szöveg különlegességét jelenti. A tanulmányában idézett több kolofon profán, játékos vágyakozását vagy kívánságát örökítette meg az egykori kó-

33 Jánó: Ungi Pál mester; valamint Ernő Marosi: Amour chevaleresque et salut dans deux peintures murales gothiques de Transylvanie = Le plaisir de l'art du Moyen Age: commande, production et réception de l'oeuvre d'art. Mélanges en hommage à Xavier Barral i Altet. Publ. Rosa Alcoy Pedros-Dominique Allios. Picard, Paris, 2012 (a továbbiakban Marosi: Amor chevaleresque). 705-713.

34 Uo. 708.

35 Giuseppe Cremascoli: L'amanuense medievale tra pietas e goliardia $=$ Scrivere e leggere nell'alto Medioevo. Spoleto 28 aprile - 4 maggio 2011. Fondazione Centro Italiano di Studi sull' Alto Medioevo, Spoleto, 2012. 607-625. https://www.academia.edu/9572963/L_ amanuense_medievale_tra_pietas_e_goliardia_in_Scrivere_e_leggere_nell_alto_ medioevo_Settimane_di_studio_della_Fondazione_Centro_Italiano_di_Studi_sull_ Alto_Medioevo_LIX_Spoleto_28_aprile_4_maggio_2011_Spoleto_Fondazione_ Centro_Italiano_di_Studi_sull_Alto_Medioevo_2012_607_625 (Utolsó megtekintés: 2021. 03. 27.) 
dexmásolóknak. Végül a nagy kolofongyújtemény szerzőjének, Bénédictins du Bouveret-nek azt az írnokokra vonatkozó megállapítását fogadta el, amely a derzsi felirat szerzőjére is érvényes lehet. Bouveret szerint az írnok nagyon gyakran fejezte ki az örömét, hogy sikerült a munkáját befejezni, vagy közvetlenül az olvasóhoz szólt, és megnevezte a másolás során elkövetett hibáit, máskor imát mondott a hibák miatt a lélek nyugalmáért. A kolofonokban egy egész sor emberi érzés nyilvánult meg, személyes közelségbe hozva a szerzőt. ${ }^{36}$

Ungi Pál szerelmi érzületének képben történő kifejezése a Szent Mihály karján ülő lány megjelenítésében konkretizálódott, akinek a fedetlen felsőteste kissé erotikus színezetet kölcsönöz az alakjának. ${ }^{37}$

„Témánkat illetően - írja Marosi Ernő - az erotikus motiváció, a szerelem és eszkatológia közti szoros kapcsolat egyáltalán nem volt rendkívüli a XV. században, sőt még meg is felelhetett a lovagi udvarlás normáinak. A mi Pál mesterünk, akit [...] szerelem és valószínúleg gyász motivált - megfelelt így annak a lovagi etikának, amelyet a szeretett hölgy iránti húségeként jellemezhetünk." ${ }^{8}$

Ehhez a gondolatmenethez illeszthetjük, illetve a lélekmérő Szent Mihály közvetítéséért való fohászként foghatjuk fel Pál mester névbekarcolását a rövid könyörgéssel, szupplikációval: „Hic fuit Paul [...] de Ung [...] pictor (?) Rex Judex.” A még puha vakolatba bekarcolta a nevét, az évszámot is feltüntetve a mester segédje is: „Hic fuit [...] Andreas (?) 1[4]19”. ${ }^{39}$ (7. kép)

\section{A SAUL MEGTÉRÉSE FALKÉP ÉS A NAGYMIHÁLYIAK}

A derzsi falképek kutatástörténetében Dávid László (1932-2007) elsőként próbálta felfedni a magát „de Ung”, azaz unginak nevező „magister” személyét, akit Nagymihályi Albert (†1433 k.) vránai perjel rokonsági körében vélt megtalálni. Idézem:

36 Vladimir Agrigoroaei: Scriptor scribebat et pulcram puellam in mente tenebat: la fin de l'inscription peinte de Dârjiu (1419). Studii și Materiale de Istorie Medie XXX(2012). 213221.

37 Ebben a szellemben festette meg Pál mester a Szent László-legenda Birkózás és Pihenés jelenetét is.

38 Marosi: Amor chevaleresque. 709.

39 Lásd még Jánó Mihály: A székelyderzsi unitárius templom Saul megtérése falkép ikonográfiája. = Székelyek a keleti végeken. 9-17. 
„[...] a Nagymihályi családból eredő »Albertus de Ung«, mint a johannita lovagrend magyarországi főnöke, erdélyi kapcsolatokkal is rendelkezik, rokonai közül sokan viselnek országnagyi tisztségeket 1392-ig, majd 1419-től ismét feltûnnek vezetô pozíciókban. Ebben a családban reméljük megtalálni a derzsi falképek megrendelőjét Albert testvérének, Istvánnak, vagy rokonának, Dezsőfi Istvánnak fiában”.

Az 1419-es évszám Dávid László szerint azért is lehet döntő időpont a derzsi falképek megrendelőjének keresésében, mert

„[...] az a tény, hogy a családból Nagymihályi Albert vránai perjel épp 1419-ben kapja a horvát báni, Garai Bánffi Dezső ugyanekkor a macsói báni tisztet, azt jelzi, hogy az 1403. évi Zsigmond-ellenes lázadásban részt vett Losonczi család 1419-ben ismét elnyerte a király kegyeit. Ha helyes nyomon járunk - írja a szerzőnk -, ennek a kifejezéseként szemlélhetjük az István fia Pál megrendeléséből készült Saul megtérése-jelenetet a székelyderzsi falképeken”. ${ }^{40}$

A megrendelő személyével kapcsolatban Benkő Elek régész véleményét is idéznünk kell:

„A vármegyei területről származó, a Székelyföldön (is) hatalmi pozícióba kerülő nemesekre az egyik leglátványosabb példát az udvarhelyszéki Székelyderzsen találjuk. Itt - a kutatás kivételes szerencséjére - a templombelső 15 . század eleji kifestéséhez egy részletesebb, datált felirat is tartozik, amely megnevezi a megrendelőt Ungi István fia Pál személyében, akit családjával együtt a festő belekomponált a déli hajófal Saul megtérése-jelenetbe. A damaszkuszi úton lováról lebukó, majd megtérő Saul (Ap-Csel 9,1-19) a későbbi Pál apostol falképen meglehetősen ritka szerepeltetése egyértelmű utalás a megrendelő személyére, még ha a bibliai történet konkrét életrajzi vonatkozásait nem is ismerjük, miként azt sem tudjuk, hogyan kerültek a Székelyföld előkelői közé az Ung megyei István leszármazottjai. [...] Ami biztos, hogy Pál mester írástudó volt, aki az építési feliratot maga szövegezte, benne a középkori könyvmásolók gyakorlatára emlékeztető fordulattal [...]". ${ }^{41}$

40 DÁvid László: A középkori Udvarhelyszék müvészeti emlékei. Kriterion, Buk., 1981. 278.

41 Benkő Elek: A középkori Székelyföld. MTA, BTK, Régészeti Intézet, Bp., 2012. 202. 
Visszatérve Dávid László feltételezésére a megrendelő személyével kapcsolatban, meg kell jegyeznünk: nem tudjuk pontosan, hogy Nagymihályi (Ungi) Albert mikortól viselte a vránai perjelség mellett a dalmát-horvát báni címet. Arra van adatunk, hogy ő magát mint e tisztségek birtokosát nevezi meg egy általa kiadott oklevélben, 1419. július 10-én: „Nos Albertus de Nagmihal prior Auranensis, ordinis Sancti Johannis Jerosolymitani, Dalmatieque et Croatie banus [...]". ${ }^{42}$

Nagymihályi Albert egyike volt Zsigmond király legmegbízhatóbb embereinek. Hủ szolgálataiért a király már 1397-ben nagymihályi birtokrészhez juttatta, amelyet testvére, László az 1387. évi, Horváti-Palisnai-féle lázadásban való részvétele miatt elveszített. ${ }^{43}$

Nagymihályi vagy Ungi Albert Zsigmond király szolgálatában szerzett katonai érdemeirôl részletesen írt Farkasfalvi Mauks Ernő (1877-1953) az Ungmegye múltjából c. tanulmányában. ${ }^{44}$

Mauks Ernőnek a gazdag levéltári forrásanyagot felhasználó munkájában olvasható, hogy:

„Albert érdemeinek legfőbb elismerése azonban az volt, hogy 1417. febr. 12-én, Konstancban kelt oklevelében Naillac Filibert, a jeruzsálemi sz. János rend nagymestere, Zsigmond király jó embere, bizonyára a király közbenjárására, neki adományozta a vránai perjelséget, mely adományt a király még azon évben jóváhagyott". ${ }^{45}$

A konstanzi zsinaton való tartózkodás idején, 1418. március 29-én Nagymihályi Albert kérésére a király neki és az egész nemzetségének adományozta - a család ungi elöljárói által korábban is használt - most kibővített címerét. ${ }^{46}$ Élete végén Nagymihályi-Ungi Albert elkísérhette még Zsigmond királyt az itáliai útján is, ő lehetett az, akit „Albertus de Hunc” néven jegyeztek fel 1432-ben Sienában, az uralkodó kíséretében. ${ }^{47}$

42 Zsigmondkori oklevéltár. Szerk. Mályusz Elemér-Borsa Iván-C. Tóth NorbertNeumann Tibor-Lakatos Bálint-Mikó Gábor. I-XIV. Akadémiai-MNL OL, Bp., 1951-2020 (MNL OL Kiadványai II: Forráskiadványok 1, 3-4, 22, 25, 27, 32, 37, 39, 41, 43, 49, 52, 55, 59. - a továbbiakban ZsO). VII. 213. (759. sz.)

$43 \mathrm{ZsO}$ I. 521. (4720. sz.)

44 Farkasfalvi Mauks Ernő: Ungmegye múltjából. Adalékok a vármegye középkori történetéhez, feltüntetve a Nagymihályi család történetének keretében. Szeged, 1905. 76-79.

45 Uo. 78.

46 Uo. 81. A címeres levélről lásd még Jé Kely Zsombor: Nagymihályi Albert címereslevele = Sigismundus rex et imperator. Müvészet és kultúra Zsigmond korában. 1387-1437. Szerk. TAKÁcs Imre. Szépmúvészeti Múzeum-Musée national d'histoire et d'art, Bp.-Luxemburg, 2006 (a továbbiakban Sigismundus rex et imperator). 410-411.

47 E. Kovács Péter: Zsigmond király Sienában. Corvina, Bp., 2014. 203. 
Részben a Nagymihályi Albertéhez hasonló királyhű történelmi szerepet követhetünk a Garai Bánfi Dezső életében is. Ezért talán mégsem tartható az a feltételezés, hogy az ő 1419. évi macsói bánként való szereplésének bármilyen összefüggése lett volna a derzsi falképekkel. Hiszen már 1408-ban országos főméltóságot viselt Zsigmond király udvarában Cillei Borbála királyné főlovászmestereként, ${ }^{48}$ majd 1409-ben mint ispánnak Pozsega megyében egyik királyi megbízottként feladata és kötelessége volt kinyomozni és kiszolgáltatni azokat, akik elmulasztották adománylevelük megerősítését, vagy nem kértek kegyelmet lázadásuk miatt. ${ }^{49}$

Nem ismerjük az időpontját annak sem, hogy mikor nyerte el Garai Dezső a macsói báni tisztséget. Nevét ebben a minőségben első alkalommal valóban egy 1419. május 26-án kelt dokumentum őrizte meg, amely azonban nem a kinevezésérôl szól, hanem, mint macsói bán, ő volt az oklevél kibocsátója. ${ }^{50}$

A Losonciak Zsigmond-ellenes 1403. évi lázadásban való részvételéről tudjuk, hogy még 1404. elején is ellenálltak a királynak, ${ }^{51}$ viszont az 1404 júniusában kelt oklevélben arról értesülhetünk, hogy Losonci István, Ferenc és Dezső hütlenségét megbocsátotta a király, ${ }^{52}$ Losonci Zsigmondnak és testvérének pedig várakat adományoz az uralkodó Zaránd és Abaúj megyében..$^{53}$

Mindezt együttvéve, le kell mondanunk Dávid László feltételezéséről, amelyet mindeddig elfogadtunk, és hivatkoztunk rá, miszerint a Nagymihályi-Losonci-Ungi család tagjainak Zsigmond király az 1403. évi felkelésben való részvétel után 1419ben megkegyelmezett, és ennek az eseménynek állított jelképes emléket abban az évben Ungi Pál mint a kiterjedt család egyik tagja a Saul megtérésének megörökítésével a székelyderzsi templomban. ${ }^{54}$

48 Engel Pál: Magyarország világi archontológiája 1301-1457. I. MTA, BTK, Történettudományi Intézet, Bp., 1996. 57, 165.

49 Mályusz Elemér: Zsigmond király uralma Magyarországon. 1387-1437. Gondolat, Bp., 1987.57.

50 Engel: i. m. 30. Hivatkozása: Diplomatikai levéltár (Q szekció), Kincstári levéltár (E) MKA, Neo-regestrata acta (Q 311) 10813. https://archives.hungaricana.hu/en/charters/1 18259/?list=eyJxdWVyeSI6ICJHYXJhaSBEZXpzXHUwMTUxIn0 (Utolsó megtekintés: 2021. 03. 29.)

51 MÁlyusz: i.m. 57.

$52 \quad \mathrm{ZsO}$ II. 382. (3223. sz.)

53 Uo. 483. (3957.sz.)

54 További tisztáznivaló: a Nagymihályi-Ungi-Losonci család egyik tagjának, Ungi Pál mesternek milyen kapcsolata lehetett azokkal a székelyföldi vagy más erdélyi falvakkal, amelyeknek a templomában a székelyderzsivel közel egy időben, ugyanazon mühely által, azonos stílusban megfestett Szent László-ciklusok vagy más témájú ábrázolások készültek. A művészettörténeti és restaurátori kutatás Csíkszentmihály, Csíkmenaság, Felsőboldogfalva, Homoród és Rádos templomainak ma látható falképeit rokonítja a székelyderzsivel, amelyek a 15. század első két évtizedében készülhettek. Lásd Jánó Mihály: A székelyderzsi 


\section{PÁLÓCI GYÖRGY ERDÉLYI PÜSPÖK (1419-1423), A SZENT LÁSZLÓ- CIKLUS MEGRENDELŐJE}

A festett feliratban jelzett 1419-es évszám alapján elképzelhető egy másik válasz arra a kérdésre, hogyan került kapcsolatba a székelyderzsi templommal az Ung megyéből származó Pál mester, akiről a nevén kívül semmi egyebet nem tudunk.

Egy megjelenés előtt álló tanulmányomban ${ }^{55}$ a székelyföldi Szent László-legendaciklusok Kivonulás-jelenetét elemezve arról kellett megbizonyosodnom, hogy csak itt, a székelyföldi templomokban látható egy püspök alakja, aki egy templom vagy vár kapujában állva megáldja a hadba vonuló László királyt. ${ }^{56}$

A püspök szerepére az 1068. évi Kerlés-hegyi ütközetet elbeszélő Képes Krónika világít rá. A magyar sereg harcba indulásáról így ír a krónika szerzője: „Pénteken kora hajnalban felkeltek, az oltáriszentség vételével mindannyian megerősítették magukat, és rendezett sorokban a pogányok elleni összecsapásra indultak" ${ }^{57} \mathrm{E}$ szövegrésszel kapcsolatban Kerny Terézia megjegyezte: „Bár a Gesta szövegéből mindössze az derül ki világosan, hogy a sereget kísérő egyházi asszisztencia csupán az ütközet előtti misét celebrálta, a későbbi évszázadok történései számos példával szolgáltak arra vonatkozóan, hogy a klérus irányította tevőlegesen az ütközeteket”. ${ }^{58}$

Az ütközetbe induló Salamon király és a hercegek számára a szertartást celebráló, majd a falképeken a Szent Lászlót megáldó egyházi személy a résztvevők élén, a király és a hercegek rangjához méltóan, nem lehetett más, mint egy főpap. Ezért szerepel egy püspök a freskóciklus Kivonulás-jelenetében, és mivel az ütközet az erdélyi

unitárius templom (Kalauz). Verbum, Kvár, 2019. 70. Ebbe a körbe sorolhatjuk a csíkszenttamási templom régészeti ásatása során felszínre került, női arcot ábrázoló falképtöredéket, amelyet a Csíki Székely Múzeum régészeti gyüjteményében őriznek. Szintén a derzsi mühely készítette a székelyszentléleki római katolikus templom északi külső falán nemrég feltárt és restaurált falképeket.

55 Jánó Mihály: A püspök megáldja a hadba vonuló Szent László királyt. Kézirat.

56 Ivan Gerát szlovák mưvészettörténész is felfigyelt arra, hogy amíg Gelencén megfestették a sereget megáldó püspök alakját, addig a Szepességben nincs erre analógia: Ivan GERÁT: Pictorial Cycles of St. Ladislas - Some Problems of Interpretation = Slovensko a Chorvátsko: bistorické paralely a vztahy (do roku 1780). Vedecká redakcia Martin Homza-Ján LukAčKaNeven Budak. Katedra slovenských dejín, Filozofická fakulta UK-Odsjek za slovačku povijest, Filozofski fakultet Comenius sveučilišta, Bratislava-Zagreb, 2013. 306. https:// www.academia.edu/20770118/Pictorial_Cycles_of_St_Ladislas_Some_Problems_of_ Interpretation; (Utolsó megtekintés: 2021. 02.20.)

57 Képes Krónika. http://mek.oszk.hu/10600/10642/10642.htm\#56 (Utolsó megtekintés: 2021. 02. 20.)

58 Kerny Terézia: A kerlési ütközet megjelenése és elterjedése az irodalomban, majd a képzómüvészetben $=$ Folklór és vizuális kultúra. Szerk. Szemerkényi Ágnes. Akadémiai, Bp., 2007. 220-221. 
püspökség dobokai főesperességének területén zajlott, jelképesen az erdélyi püspökre is gondolhatunk. Bár ábrázolását nem köthetjük konkrét személyhez, feltételezhető, hogy alakját a középkori erdélyi püspökség egész területén megfestették a Szent László-legenda képsorában, és a megrendelő is többnyire a püspökség intézménye lehetett. Ebből következtetve pedig, az 1419-ben készült székelyderzsi Szent Lászlólegenda és a templomhajó déli hosszfalán megfestett falképegyüttes megrendelésében vélhetően Pálóci Györgynek (†1439) mint Erdély püspökének döntő szerepe lehetett.

Temesváry János Erdély középkori püspökei c. könyvében írja, hogy Pálóci György 1419 tavaszától töltötte be az erdélyi püspöki tisztséget:

„Zsigmond király amint az egyetemes egyház és a pápák sorsa fölött döntött, úgy intézkedett az egyes püspökségekről is. Így töltötte be Upori István elhunyta után, 1419 tavaszán az erdélyi püspökséget is, midőn Pálóczy György szepesi prépost személyében új fôpásztort adott az üresedésben levő s árvaságra jutott egyházmegyének. Sőt ezúttal a kegyúri bemutatás jogát oly módon gyakorolta, hogy a tőle kinevezett föpapot azonnal a püspökség birtokába is iktatta". 59

V. Márton pápa csak 1419. július 31-én nevezte ki Pálócit erdélyi püspökké. ${ }^{60}$ Később, az 1419. december 20-án kelt levelében ezt írta: „[...] György erdélyi püspök, akkor szepesi prépost az erdélyi püspökség javainak kormányzásába és igazgatásába az pásztor nélkül lévén még az ő általa történt kinevezése előtt magát beleártotta és azt háborítatlanul gyakorolta $[\ldots] ”{ }^{61}$

„Pálóczy, aki történelmi szereplésének jelentőségével magasan kiemelkedik a 15. században élt püspökök sorából - írja Temesváry János -, annak az előkelő és nevezetes fóúri családnak volt a sarjadéka, amely magát eleinte [...] Pányokinak írta. Ezt a nevet azonban utóbb a családnak egyik ága, amelyhez fópapunk is tartozott, elhagyta és az 1327-ben Károly Róbert királytól adományba kapott ungmegyei Pálóczról, [...] Pálóczynak kezdette magát neveztetni.”22

59 Temesváry János: Erdély középkori püspökei. Cluj-Kvár, 1922. 310.

$60 \mathrm{ZsO}$ VII. 224. (821. sz.)

61 Uo. 283. (1159.sz.)

62 Temesváry: i.m. 
Az Ung megyei Pálóci családból származó György püspök feltételezhető szerepét a székelyderzsi templom falképeinek megrendelésében néhány olyan tényező erősítheti meg, amely a személyes egyházi pályájában, valamint Zsigmond király és udvara Szent László-kultuszában kereshető.

Pálóci György az egyházi pályáján előbb mint szepeshelyi kanonok, majd 1400tól 1419-ig szepesi prépost szerepel. Fiatalsága ellenére a szepesi prépostként való kinevezését a király környezetéhez tartozó testvérei, Máté és Imre érték el, ám úgy látszik, hogy György alig tartózkodott a préposti székhelyén, mert emiatt a káptalan többször megpróbálta eltávolítani. A prépostság történetét lejegyző Pirhalla Márton (1852-1922) jellemzése szerint: „Különben is olyan fiatal volt György, hogy alig hagyta el ama kort, melyben az akkori egyházi törvények szerint a tonsurát felvehette volt". ${ }^{63}$

Pálóci György Zsigmond király kitartó támogatásának köszönhetően viselte csaknem két évtizedig a jól jövedelmező préposti címet, és eközben elóbb Krakkóban (1408), ${ }^{64}$ majd Bécsben (1409-1412) ${ }^{65}$ folytatta az egyetemi tanulmányait. Az 1410es években pedig gyakran kísérte a királyt az európai útjain, ${ }^{66}$ pl. a konstanzi zsinat időszakában (1414-1418) Nagymihályi Albert vránai perjellel együtt. ${ }^{67}$

A szepesi prépost a számtalan utazás és az egyetemi évek között gyakorlatilag csak 1401 és 1404 között tartózkodhatott a Szepességben. ${ }^{68}$ Azonban, e rövid idő elég lehetett arra, hogy a szepeshelyi (Spišská Kapitula) Szent Márton-templomban látott Károly Róbert megkoronázása falfestmény mellett tudomást szerezzen, vagy akár személyesen is láthasson néhányat azokból a Szent László-legenda-falképsorozatokból, amelyeket nagy számban megfestettek a vidék templomaiban a 14. században. ${ }^{69}$

63 Pirhalla Márton: A szepesi prépostság vázlatos története kezdetétól a püspökség felállitásáig. Lőcse, $1899.69,78$.

64 Haraszti Szabó Péter-Kelényi Borbála-Szögi László: Magyarországi diákok a prágai és a krakkói egyetemeken 1348-1525. II. ELTE Levéltára-MTA - ELTE Egyetemtörténeti Kutatócsoport, Bp., 2017 (Magyarországi diákok a középkori egyetemeken 2). 82.

65 TüsкÉs Anna: Magyarországi diákok a bécsi egyetemen 1365 és 1526 között. ELTE Levéltára, Bp., 2008 (Magyarországi diákok a középkori egyetemeken 1). 79.

66 ENGel Pál: Zsigmond bárói: rövid életrajzok = Müvészet Zsigmond király korában.1387-1437. Szerk. Beke László-Marosi Ernő-Wenli Tünde. Budapesti Történeti Múzeum, Bp, 1987 (a továbbiakban Müvészet Zsigmond király korában). 405.

67 BÁrÁny Attila: Zsigmond király 1416-os angliai kísérete. Aetas 19(2014). 3-4. sz. 5-30.

68 Pirhalla: i. m.78.

69 Napjainkban a következő helységek templomaiban van tudomásunk a legenda (historia) ábrázolásáról: Nagy-vagy Kakaslomnic (Vel'ká Lomnica), Ruszkin (Ruskinovce), Svábfalva (Švábovce), Szepesdaróc (Dravce), Szepesmindszent (Bijacovce), Szlatvin (Slatvina), Vitfalva (Vítkovce), Zsigra (Žehra). 
A Szent László-legenda falképeinek Ung megyei emlékéről nemrég értesülhettünk. Engel Pál kutatásai alapján tudjuk, hogy a Pálóci család Ung megyei birtokai között szerepelt 1398-ban Komoróc, Palágy helység ${ }^{70}$ (ma Palágykomoróc, Palagy Komarivci, Ukrajna), amelynek református templomában a közelmúltban tártak fel egy három jelenetből álló Szent László-legendaciklust. ${ }^{71}$

A 14. században fellendülő László-kultusz Luxemburgi Zsigmond uralkodásának időszakában (1387-1437) az udvar, az egyház és a főnemesi réteg hozzájárulásával kiteljesedett. Ebben a korszakban készült a középkori Szent László-ábrázolások többsége. Czudar János váradi püspök (1383-1395), Szent László nagy tisztelője bízta meg a szent lovas szobrának elkészítésével Márton és György mestert (magistert), amelyet 1390-ben állítottak fel a Boldogságos Szűz Mária-székesegyház előtt. ${ }^{72}$ A derzsi falképekkel körülbelül egy időben, Andrea di Filippo Scolari püspök (14091426) idején készült a szent váradi fejereklyetartója. ${ }^{73}$

Szent László emlékezetét számos más ábrázolás elevenítette fel és őrizte a 14. század végén és 15. század első évtizedeiben. Nagyrészüket Kerny Terézia (19572015) foglalta össze 1987-ben. ${ }^{74}$

Fontos lehet Pálóci Szent László iránti érdeklődésének kialakulásában, hogy jelen volt Konstanzban, ${ }^{75}$ amikor az uralkodó megrendelésére a helybeli Heinrich Grubel festő, Caspar Sünder és Johannes Ledeshoser közremúködésével kifestették az egykori Ágoston-rendi, ma Szentháromság-titulusú templomot, amelyben az Ágoston-

70 Engel Pál: Ung megye településviszonyai és népessége a Zsigmond-korban. Századok 119(1985). 4. sz. 966.

71 Kiss Lóránd: A palágykomoróci református templom falképeinek feltárása = Középkori templomok a Tiszától a Kárpátokig. Szerk. Kollár Tibor. Szabolcs-Szatmár-Bereg Megyei Területfejlesztési és Környezetgazdálkodási Ügynökség Nonprofit Kft., Nyíregyháza, 2013. 258-261. A falképeket röviden leírja még Jékely Zsombor: A korai Szent László-ciklusok narratív rendszere és elóképei $=$ Szent László kora és kultusza. Szerk. Kerny Terézia-Mikó Árpák-Sмонау András. Székesfehérvári Egyházmegyei Múzeum, Székesfehérvár, 2019 (Székesfehérvári Egyházmegyei Múzeum Kiadványai 13). 81.

72 Kerny Terézia: Szent László lovas ábrázolásai = Uő: Uralkodók és királyi szentek. MTA, Mưvészettudományi Kutatóközpont, Mưvészettörténeti Intézet, Bp., 2018.124.

73 Evelin Wetter: Szent László ereklyetartó mellszobra = Sigismundus rex et imperator. 378382.

74 Kerny Terézia: Szent László-kultusz a Zsigmond-korban = Müvészet Zsigmond király korában. 353-363. Tanulmányának későbbi változata 2018-ban jelent meg. Uő: Magyar szent királyok tisztelete és ikonográfiája a XIII. századtól a XVII. századig = Uő: Uralkodók, királyi szentek. Válogatott ikonográfiai és kultusztörténeti tanulmányok. MTA, Bölcsészettudományi Kutatóközpont, Múvészettörténeti Intézet, Bp., 2018. 35-40.

75 Engel Pál: Zsigmond bárói. Rövid életrajzok = Müvészet Zsigmond király korában. 435. Egyházi pályafutásáról, tevékenységéről Beкe Margit: Pálóczi I. György = Esztergomi érsekek. 1001-2003. Szerk. Beke Margit. Szent István Társulat, Bp., 2003. 201-203. 
rend története, próféták és más ábrázolások mellett az árkádívek közeiben elkészítették Zsigmond király és Szent László portréját is. ${ }^{76}$

Végezetül, bár nem ismerek egyetlen olyan írásos dokumentumot sem, amely Pálóci György művészetpártolását örökítette volna meg az erdélyi püspöksége idején, biztosak lehetünk abban, hogy a királyi udvar Szent László-kultuszának hatása Erdélyben is végigkísérte, és azt megpróbálta érvényesíteni az egyházmegyéjében. Az alatt a néhány év alatt, amíg Erdélyben tartózkodott (1419 és 1423 között), a környezetében épitészek és festők is megfordulhattak. Könnyen elképzelhető, hogy „,öldije”, Ungi Pál is közöttük volt, akivel együtt a székelyderzsi templom falfestményekkel való „díszítését” 1419-ben festő-donátorként és megrendelóként létrehozták.

\section{THE PAINTED TRIPTICH OF THE DÂRJIU CHURCH}

Keywords: customer; donor; self-portrait; intercession

Most of the wall paintings of the fortified church in Dârjiu/Székelyderzs, Szeklerland (Harghita county, Romania) which can be seen today, were painted in 1419. The author of the study aimed at art historical research and iconographic analysis of the scenes of saint bishops, the Archangel St. Michael and the conversion of Saul on the south side of the nave, as a result of which he pointed out that this series was painted by and donated to the church by Master Pál Ungi. The image cycle of the legend of St. Ladislaus, located on the north side of the nave, which was also painted by Pál Ungi and his workshop, was commissioned by Bishop of Transylvania, György Pálóci (1419-1423).

\section{TRIPTICUL PICTAT AL BISERICII DE LA DÂRJIU}

\section{Cuvinte-cheie: comanditar; donator; autoportret; intercesiune}

Picturile murale ale bisericii fortificate din Dârjiu/Székelyderzs (județul Harghita) au fost executate în anul 1419. Autorul studiului abordează pe scurt istoria cercetării și iconografia picturilor de pe peretele de sud al navei bisericii, reprezentând sfânții epsicopi, Arhanghelul Sfântul Mihail și scena convertirii Sfântului Paul. Ca rezultat al studiului se poate afirma, ca

76 A templom falképeinek 2004 és 2006 között végzett restaurálásának befejezése előtt még csak Kerny Terézia beszélt a Szent László-ábrázolásról, Konrad Bernd 2006-ban nem említette meg. Lásd Konrad BERnd: Falfestmények a konstanzi egykori Ágoston-rendi templomban = Sigismundus rex et imperator. 162. Jékely Zsombor helyszíni vizsgálata és az általa készített fénykép alapján tudok arról, hogy egy látványosan restaurált Szent László-falkép díszíti ma a templomot. 
picturile murale din 1419 au fost executate de meșterul și totodată donatorul Ungi Pál, cel care a fost autorul și al ciclului Sfântul Ladislau, comandat de episcopul Transilvaniei, Pálóci György, între anii 1419-1423.

\section{KÉPJEGYZÉK/LIST OF ILLUSTRATIONS/LISTA IMAGINILOR}

1. Falképek a templomhajó déli falán/Mural paintings on the south wall of the nave/Picturile murale de pe peretele de sud al navei

2. Saul megtérése-jelenet/Conversion of Saint Paul/Convertirea Sfântului Pavel

3. Ungi Pál festő önarcképe/Self-portrait of the artist Ungi Pál/Autoportretul pictorului Ungi Pál

4. Biblia-illusztráció (1 Királyok 7, 1-12)/Biblical illustration on the Book of Kings I (7, 1-12)/ Ilustrație la Prima carte a Regilor (Cap. 7, 1-12)

5. A zászló felirata/The inscription of the flag/Inscripția drapelului

6. Szent Mihály arkangyal/Archangel Saint Michael/Arhanghelul Sfântul Mihail

7. Ungi Pál névbekarcolása/Graffito with the name of Ungi Pál/Grafitul cu numele lui Ungi Pál 


\section{JÁNÓ MIHÁLY}

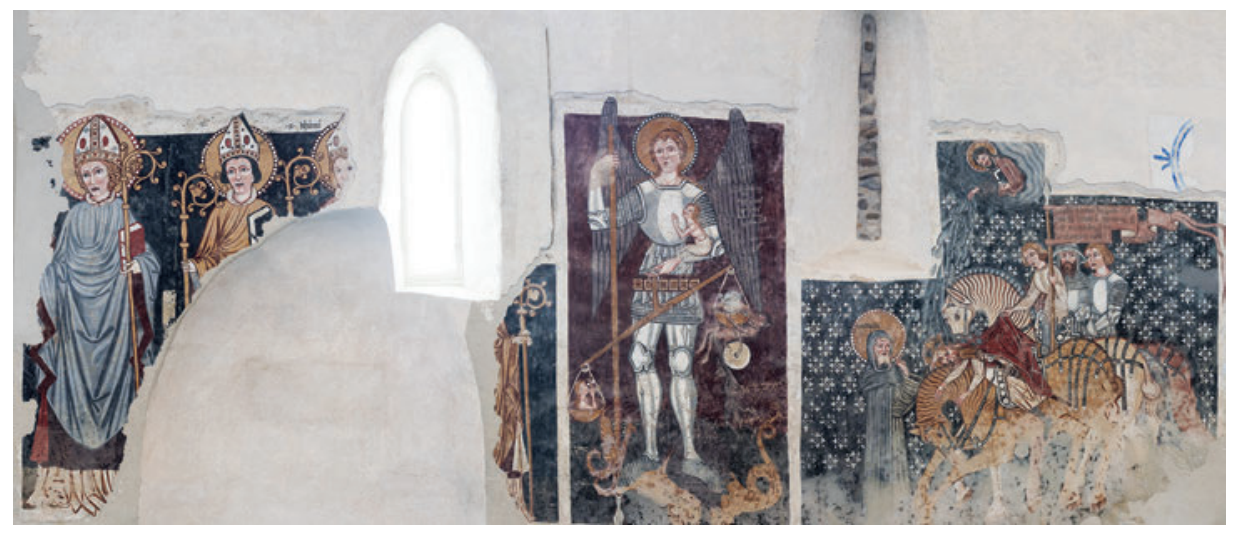

1. Falképek a templombajó déli falán

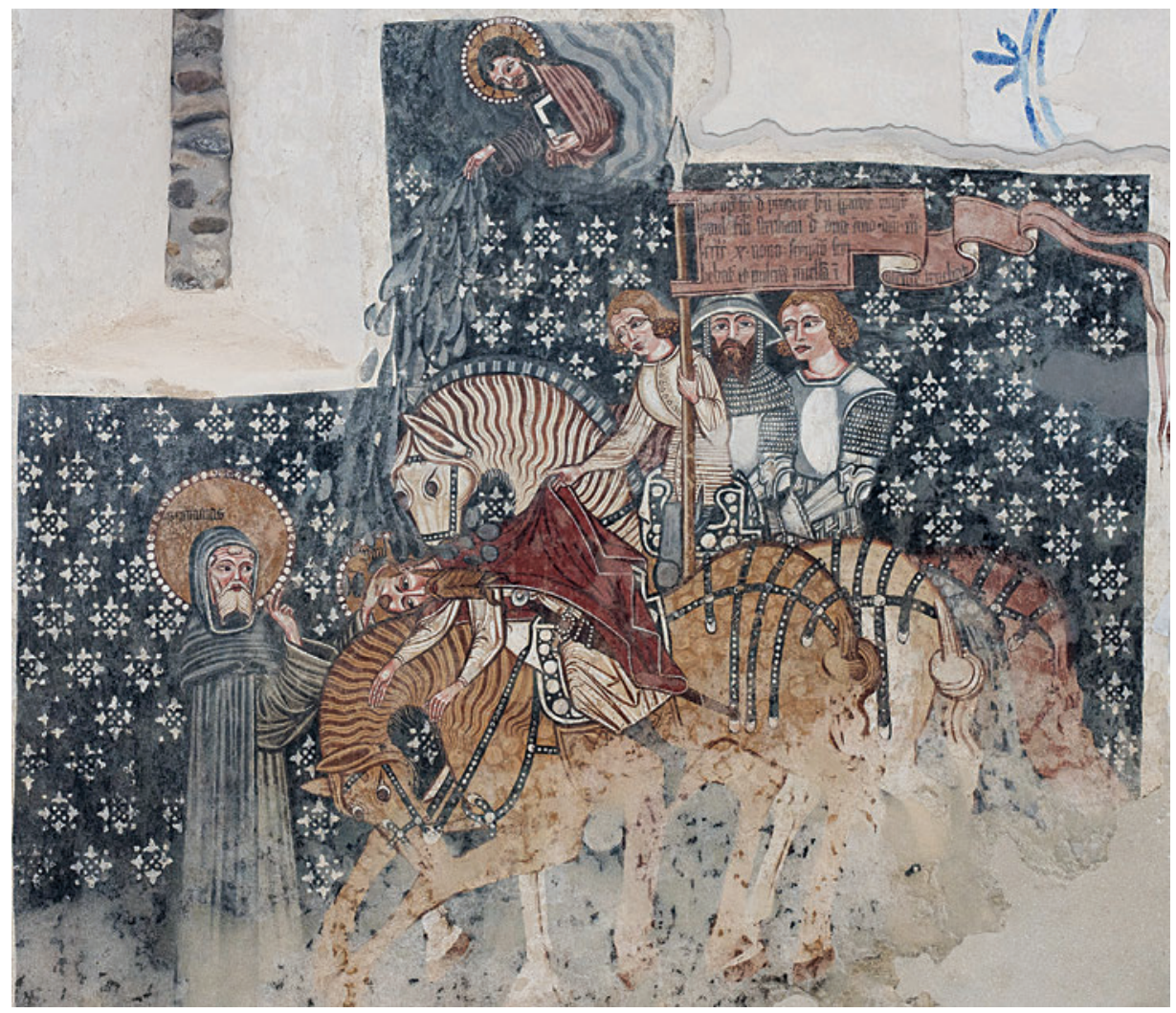

2. Saul megtérése-jelenet 


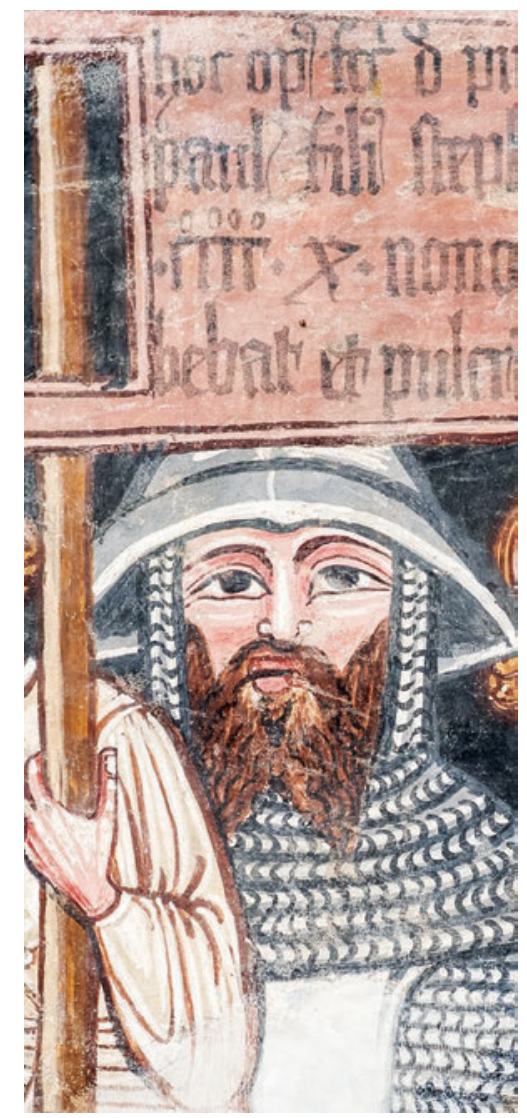

3. Ungi Pál festóö önarcképe

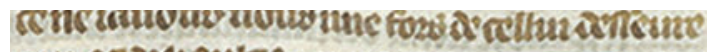

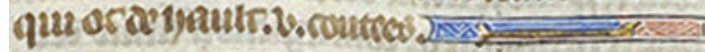

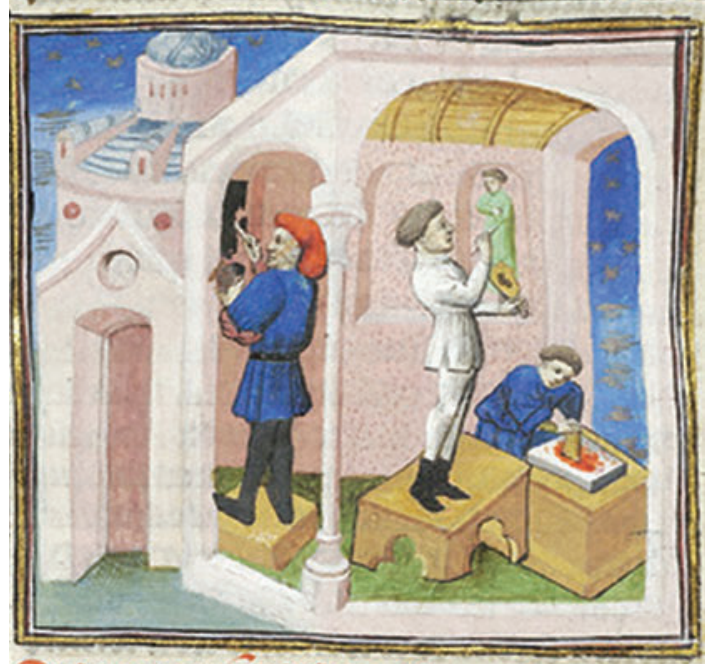

Ocinoumicuiraliancion scritefuge:

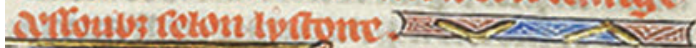

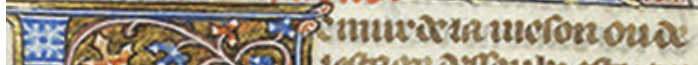
M. 0 intrare anloubz ctortey

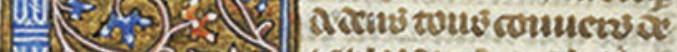

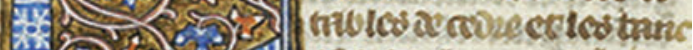

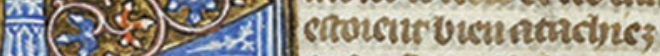

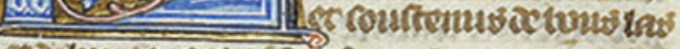

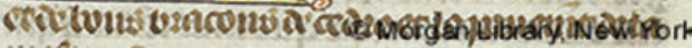

4. Biblia-illusztráció (1 Királyok 7, 1-12)

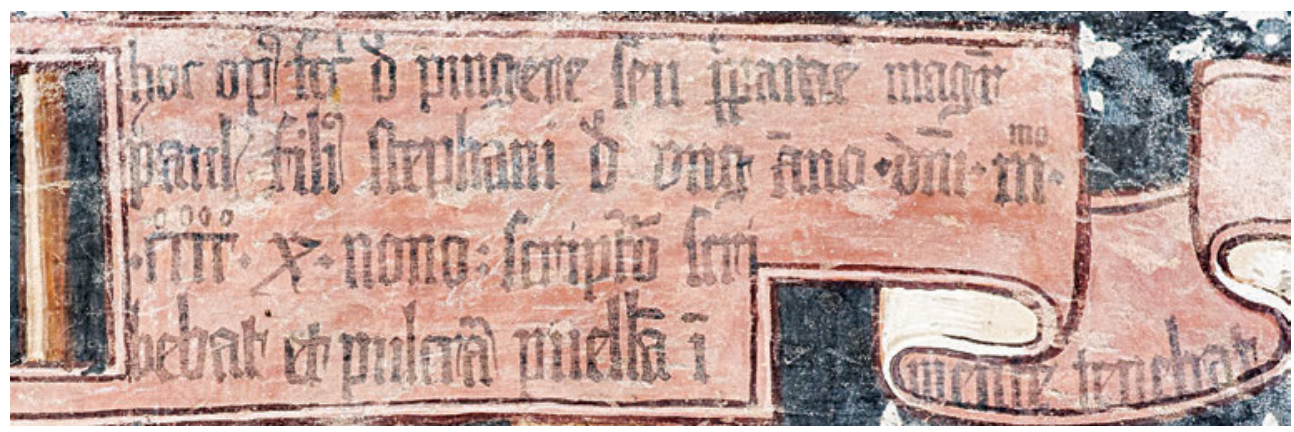

5. A zászló felirata 
JÁNó MiHÁLY

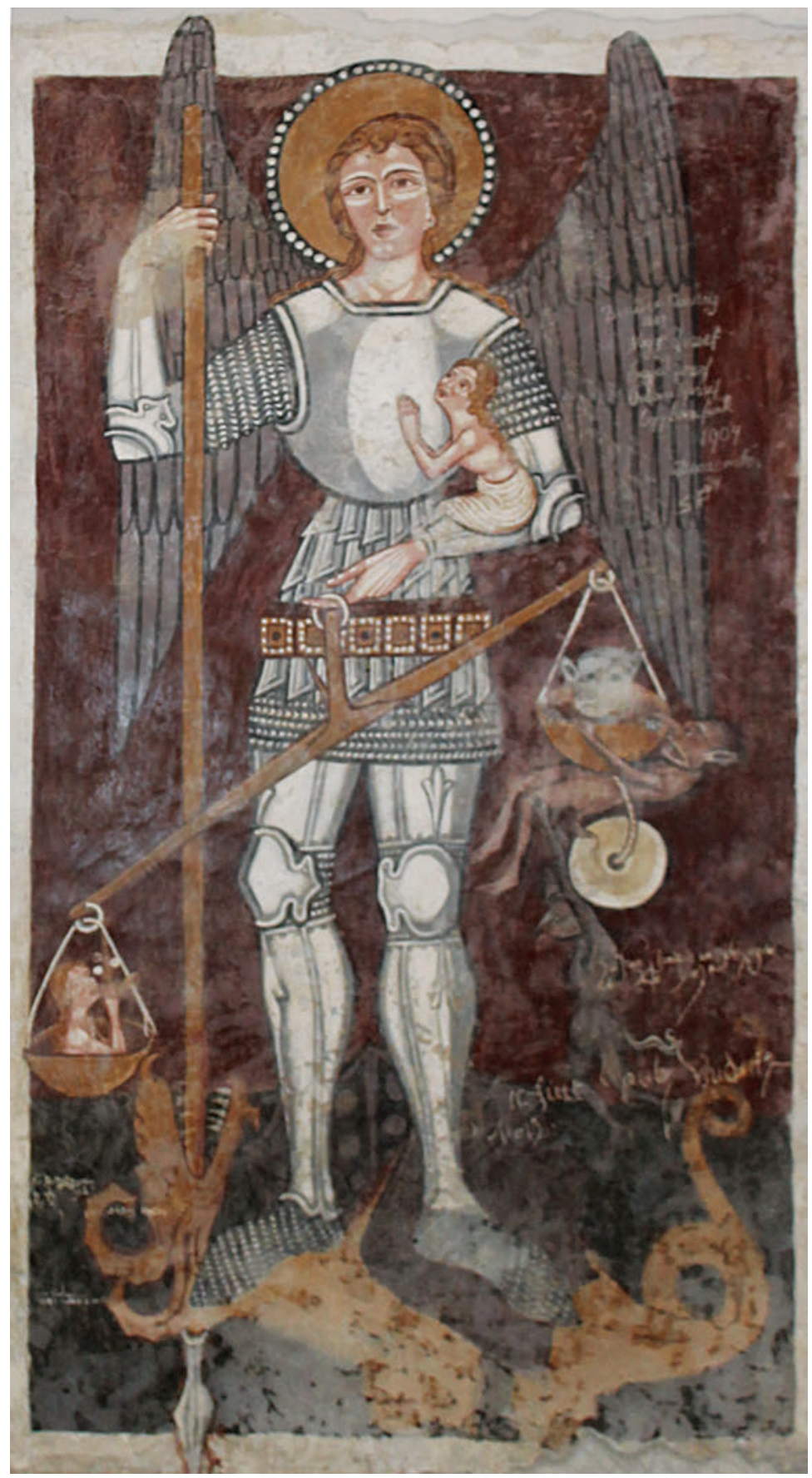

6. Szent Mihály arkangyal 


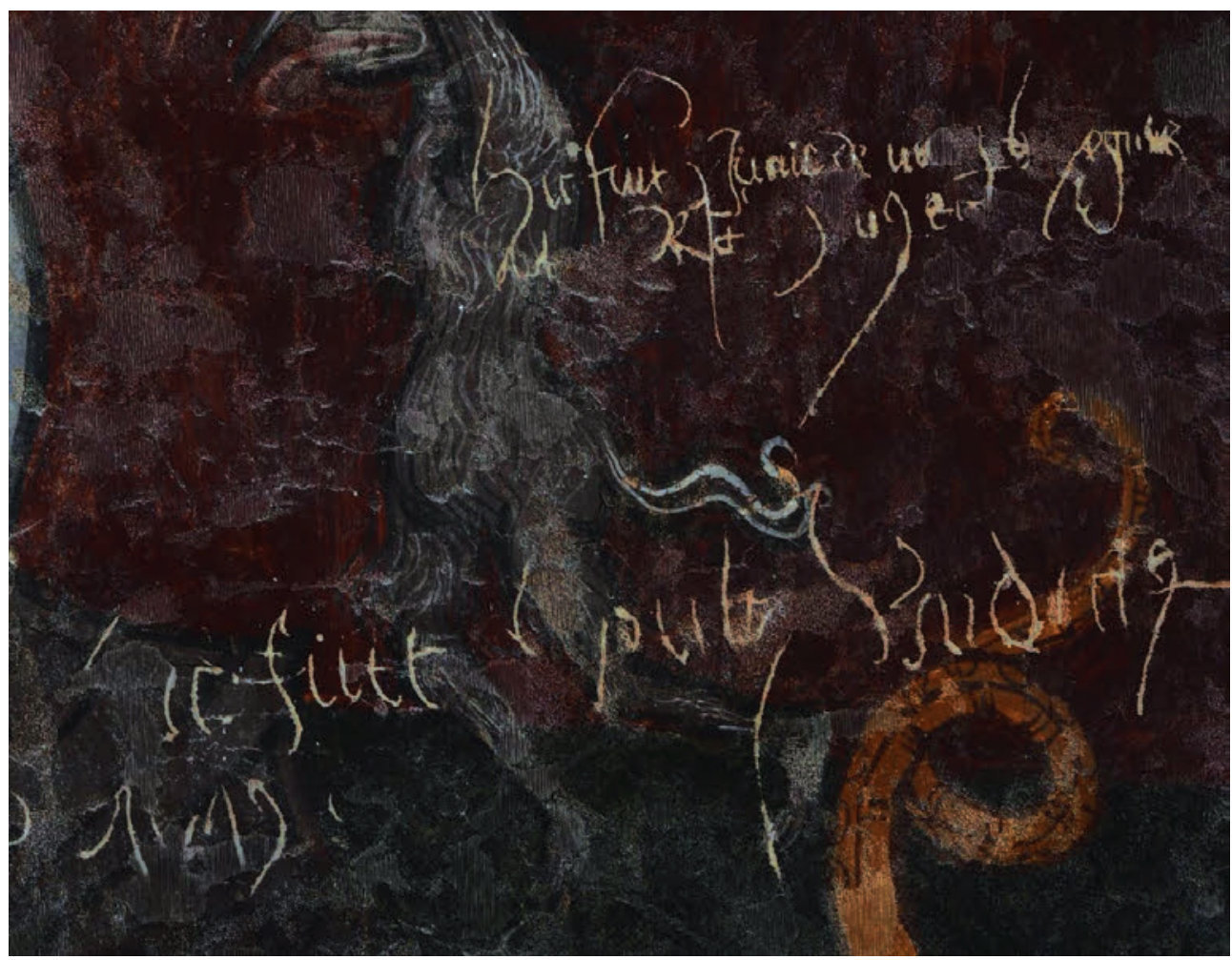

7. Ungi Pál névbekarcolása 